\title{
Sesame Oil
}

National Cancer Institute

\section{Source}

National Cancer Institute. Sesame Oil. NCI Thesaurus. Code C66537.

The edible oil extracted from the seeds of Sesamum indicum. Sesame oil is used as a cooking oil and as a food ing redient. It is also used as an ing redient in medicinal preparations. 